\title{
THE INFLUENCE OF BIOLOGICAL PREPARATIONS AND THEIR MIXTURES ON SOIL AGROCHEMICAL PROPERTIES IN WINTER WHEAT
}

Lina Marija BUTKEVIČIENĖ, Department of Agroecosystems and Soil Sciences, Faculty of Agronomy, Vytautas Magnus University, K. Donelaičio g. 58, LT-44248 Kauno, Lithuania, lina.butkeviciene@vdu.lt

Vaida STEPONAVIČIENE், Department of Agroecosystems and Soil Sciences, Faculty of Agronomy, Vytautas Magnus University, K. Donelaičio g. 58, LT-44248 Kauno, Lithuania, vaida.steponaviciene@ vdu.lt (corresponding author)

Vaclovas BOGUŽAS, Department of Agroecosystems and Soil Sciences, Faculty of Agronomy, Vytautas Magnus University, K. Donelaičio g. 58, LT-44248 Kauno, Lithuania, vaclovas.boguzas@ vdu.lt

Lina SKINULIENÉ, Department of Agroecosystems and Soil Sciences, Faculty of Agronomy, Vytautas Magnus University, K. Donelaičio g. 58, LT-44248 Kauno, Lithuania, lina.skinuliene@ vdu.lt

Tadas KERDOKAS Department of Agroecosystems and Soil Sciences, Faculty of Agronomy, Vytautas Magnus University, K. Donelaičio g. 58, LT-44248 Kauno, Lithuania, tadas.kerdokas@alumni.vdu.lt

Intensive tillage accelerates soil erosion, reduces the content of organic matter and carbon in the soil. Scientists around the world talk extensively about soil conservation policies. The process of accumulation and maintenance of soil organic matter is important for the long-term preservation of agro-system productivity. Crop production technologies applied should increase carbon sequestration in the soil (Kaiser, Kalbitz, 2012; Baumhardt et al., 2015).

The study was conducted in 2018-2019 in the winter wheat crop "Sailor". An experiment with two factors was performed: preparations of biological origin and their mixtures were used with the application of different tillage technologies. The aim of this study is to determine the effect of biological preparations on soil agrochemical properties in winter wheat crop using different tillage technologies.

The use of biological preparations and their mixtures, in many cases, increased the content of water-soluble (labile) carbon in the soil comparing compensatory nitrogen $8 \mathrm{~kg} \mathrm{t}$ of straw, without biological preparations to stimulate straw mineralization. The content of labile carbon was particularly increased by mixtures of two preparations $($ Ruinex + Penergetic $k$, Ruinex + Azofix and Penergetic $k+$ Azofix) using both tillage technologies: when applying no-tillage, the content of soluble carbon increased from $2.9 \%$ to $12.2 \%$, and when using the mixtures in ploughless tillage - from $1.4 \%$ to 10.3 . The combination of the three preparations increased the content of soluble carbon by $5.4 \%$ more in ploughless technology, in no-tillage - only $0.5 \%$. The use of one-component biological preparations in ploughless tillage also increased the content of water-soluble carbon, and in no-tillage - reduced it but insignificantly.

Keywords: biological preparations, winter wheat, soil agrochemical properties.

\section{INTRODUCTION}

As the number of people around the world increases, so does the need for food. It is no secret that agriculture is one of the largest food suppliers. Therefore, agriculture is intensifying to meet the demand. New, heavy machinery is emerging, using large amounts of fertilizers and pesticides, allowing to obtain considerable yields. However, all these measures also have a negative impact on the main means of agricultural production - soil (Staugaitis et al., 2016).

The use of mineral fertilizers in large quantities stimulates the soil acidification processes. In recent years, there have often been discussions on the negative effects of pesticides to the environment. Over time, the soil begins to degrade, and an intensive use of plant protection measures worsens the condition of the soil, as the destruction of pathogens also destroys and regenerates soil bacteria. Intensive tillage and the use of chemicals have been observed to unbalance the natural biological processes in the soil (Tripolskaja, Šidlauskas, 2010). There is a lack of knowledge about the patterns of organic matter decomposition and soil degradation reduction opportunities (Arlauskienė et. al., 2014). Plant residues are considered a vital natural resource to protect and maintain soil and crop productivity. The use of crop residues is beneficial for maintaining or improving soil organic matter (Kumar . et al., 2019). However, plant residues alone are not enough to restore the nutrients harvested, which raises the question of what measures could be taken to revitalize the soil

Copyright (C) 2021 The Authors. Published by Vytautas Magnus University. This is an open-access article distributed under the terms of the Creative Commons Attribution License (CC BY 4.0), which permits unrestricted use, distribution, and reproduction in any medium, provided the original author and source are credited. 
and how to maintain plant productivity. It is no coincidence that popular biological preparations are increasingly more used (Jakienè, Venskutonis, 2008).

The growing demand for crop products encourages the expansion of crop areas and the intensification of field plant growing technologies (Jakiene, 2011). The accumulation of soil organic matter is an important process for maintaining the long-term productivity of agro-systems, therefore, plant cultivation technologies should increase the accumulation of $\mathrm{C}$ in the soil ( $\mathrm{Lal}, 2011)$. Although the intensity of decomposition of organic matter is also determined by the abundance of soil microorganisms, on the other hand, the ratio of carbon to nitrogen in the soil may allow integrated assessment of conglomerations or concentrations of key biomass structural elements (Mikučionienè et al., 2017.

Biological preparations are a very promising area modern agriculture. These preparations are of natural origin, completely degradable and not toxic to plants or humans. The use of biological preparations does not pollute the environment, leaving no harmful residues in the crops (Paradikovic et al., 2011).

The biological preparation Ruinex contains Trichoderma sp. type of fungi, which are among the most common microbes used in agricultural systems. This fungus also secretes antibiotics by secreting enzymes. Therefore, this fungus can effectively protect plants from pathogens, and its secreted enzymes increase the content of organic matter by decomposing plant residues, and when it is mineralized, nutrients become available to plants (Sheridan et al. 2014).

The aim of this study is to determine the effect of biological preparations on soil agrochemical properties in winter wheat crop using different tillage technologies.

\section{RESEARCH METHODS}

The field experiment was performed at the Test Station of Vytautas Magnus University Agriculture Academy. The study was conducted in 2018-2019 in the winter wheat crop "Sailor". An experiment with two factors was performed: preparations of biological origin and their mixtures were used with the application of different tillage technologies.

Experimental variants: Factor A: tillage 1. No-tillage; 2. Ploughless tillage (disking). Factor B: Measures to improve soil quality and reduce risk: 1 . Compensatory nitrogen $8 \mathrm{~kg} \mathrm{t}$ of straw, without biological preparations; 2 . Ruinex $11 \mathrm{ha}^{-1} ; 3$. Penergetic k 0.21 ha $^{-1}$; 4. Azofix 11 ha $^{-1}$; 5. Ruinex 11 ha $^{-1}+$ Penergetic k 0.21 ha $^{-1}$; 6. Ruinex 11 ha $^{-1}+$ Azofix 0.51 ha ${ }^{-1} ;$. Penergetic k 0.21 ha $^{-1}+$ Azofix 11 ha $^{-1}$; 8. Ruinex 11 ha $^{-1}+$ Penergetic k 0.21 ha $^{-1}+$ Azofix 0.51 ha $^{-1}$.

Fields accounted $-60 \mathrm{~m}^{2}$. The crop was divided into four replicates.

According to the field experiment, compensatory nitrogen was applied to the stubble, sprayed with different biological preparations and their mixtures. In half of the experiment, (in case of cloudy weather) the plant residues were immediately (within 1 hour) inserted into the soil at a depth of 5-7 cm with a Cartier CR 300 (Vaderstäd) disc cultivator (no-till technology). The rest is left uncultivated (no-till technology).

The following biological preparations were used in the experiment:

Ruinex is a biological preparation designed to activate the decomposition and mineralization of plant residues. The preparation contains the fungus Trichoderma sp., which has an antibacterial effect, secretes antibiotic substances that protect plants from pathogens, reduces their activity. It is suitable for all types of soils, restores their natural properties. The preparation is enriched with phytohormones, which, when introduced into the plant, regulate cellular processes, stimulate plant growth and development. Due to the above-mentioned properties of the preparation, the productivity of field plants increases. The preparation can be used in mixtures with other biological preparations and with glyphosates.

Penergetic $\mathrm{k}$ improves the mineralization and humification processes of plant residues, supports the natural soil fertility. To accelerate the mineralization of straw, the preparation can be used in combination with azobacterial preparations. Such a combination promotes the destruction and transformation of straw into more complex compounds. Penergetic k can also be used to promote aerobic processes in compost and manure, and to reduce nutrient leaching. The preparation is used in compost and manure storage areas, and it is also recommended to use in barns after each scattering.

Azofix biological preparation contains Azotobacter sp. bacteria, which, by decomposing organic matter, fix atmospheric nitrogen and make it available to plants, increase the soil nitrogen, and improve its structure.

Soil for agrochemical analyses was taken from each variant in 15 places at a depth of $0-10 \mathrm{~cm}$, with an agrochemical drill after harvesting the pre-crop spring wheat (2018) and after application of the studied measures, next year's winter wheat harvest (2019). The total nitrogen was measured by the Kjeldahl method (\%), carbon contents (\%) were measured using a Heraeus analyser. The content of mobile humic substances was determined by photometric procedure at the wavelength of $590 \mathrm{~nm}$ using the UV-VIS spectrophotometer Cary 50. The content of water-soluble carbon $\left(\mathrm{CH}_{2} \mathrm{O}\right)$ was analysed using an ion chromatograph SKALAR (Skalar Analytical B.V., Netherlands). The analyses were performed at the Agrochemical Research Laboratory of the Institute of Agriculture of Lithuanian Research Centre for Agriculture and Forestry.

Statistical evaluation of the research was performed using computer programs: ANOVA, package "Selection". The significance of the differences between the means was determined according to the Fisher criterion and the Least Significant Difference $\mathrm{R}_{0.05}$ under $95 \%$ probability level ( $\left.\mathrm{P}<0.05\right)$ (Raudonius, 2017).

\section{RESEARCH RESULTS AND DISCUSSION}

During the experiment, after the spring wheat harvest, soil samples were taken to determine the content of watersoluble carbon, total phosphorus and mobile humic substances and acids (mobile humic substances (MHS) (\%), and acids (MHA) (\%)) in the soil (Table 1). 
Water-soluble soil carbon (labile) is particularly rapidly changing. It enters into low-molecular-weight organic compounds that are easily decomposed and rapidly degraded by soil microorganisms (Staugaitis et al., 2016). Concentrations of water-soluble carbon depend on the genesis of the soil, its horizon (layer), vegetation as well as fertilization (Zhang et al., 2011; Staugaitis et al., 2016).

In most variants, the content of water-soluble carbon, although not significantly, increased after the use of biological preparations (Table 1). Compared to the use of compensatory nitrogen to promote straw mineralization, this trend was more pronounced in crops when using mixtures of two preparations (Ruinex + Penergetic $k$, Ruinex + Azofix and Penergetic $k+$ Azofix). The use of different tillage technologies also did not have a significant effect on the evolution of labile carbon. In addition to tillage technology, the most soluble carbon was increased by spraying Ruinex + Penergetic $k$ on stubble (12.2\%), and in no-till technology - by using Azofix outside the mixture (14.7\%). No significant changes were observed with the combination of all three preparations: the addition of biological preparations increased the soluble carbon by $5.4 \%$, and only by spreading the stubble - by $0.5 \%$. Also, without tillage and using Ruinex and Penergetic $k$, a reduction in labile carbon was observed, but it was insignificant.

G. Staugaitis (2016) with co-authors also studied the content and variability of labile carbon in the soil and found the highest content of labile carbon in the soil where the test fields were fertilized by-product of biogas production. The lowest content of labile carbon was found when fertilizing with mineral fertilizers. The most intensive processes of soil carbon transformation took place in the upper layer $(0-10 \mathrm{~cm})$, which led to the largest $\mathrm{C}_{\text {org. }}$ accumulation in separate years. It can be assumed that when fertilizing with mineral fertilizers, straw alone is not enough to maintain a nondecreasing content of $\mathrm{C}_{\text {org. }}$ in the soil.

The organic carbon content of the soil was not significantly affected by tillage technology, and the use of biological preparations and their mixtures increased the organic carbon content of the soil. The use of mixtures of biological preparations Ruinex + Penergetic $k(15.6 \%)$, Ruinex + Azofix (13.6\%), Penergetic $k+$ Azofix $(8.4 \%)$ and the use of a mixture of all three preparations (25.0\%) significantly increased the organic carbon content. The use of one-component preparations Ruinex and Penergetic k also significantly contributed to the increase of organic carbon content. It can be concluded that for the increase of organic carbon in the soil, it is better to use the preparation Azofix and mixtures with it, because its effect is slower and more stable than that of nitrogen fertilizers. The concentration of nitrogen fertilizer increases significantly immediately after spreading, and a sudden increase has a negative effect on the organic carbon content of the soil.

Phosphorus is one of the key elements necessary to support all life forms. Due to the low solubility in water, phosphorus often becomes a missing element in the soil, especially at the beginning of vegetation, when the root system of the plant is weak and the soil is not yet warm enough. Soil adsorption of phosphorus depends on soil properties, clay mineral content and can be increased by increasing ion sorption. Phosphorus can be sorbed in soil nanopores, which are often present in iron or aluminum oxides and thus become inaccessible to plants (Arai, Sparks, 2007).

Table 1. The influence of biological preparations and their mixtures on the content of water-soluble carbon $\left(\mathrm{g} \mathrm{kg}^{1}\right)$, organic carbon $(\%)$, total phosphorus (\%), mobile humic substances (MHS) (\%), and acids (MHA) (\%)

\begin{tabular}{|c|c|c|c|c|c|}
\hline \multirow{2}{*}{$\begin{array}{l}\text { Biological preparations and their mixtures } \\
\text { (Factor B) }\end{array}$} & $\mathrm{C}_{\text {soluble }} \mathrm{g} \mathrm{kg}^{-1}$ & Corg. & $\mathrm{P}_{\text {total }} \%$ & MHS \% & MHA\% \\
\hline & \multicolumn{5}{|c|}{ No tillage (Factor A) } \\
\hline $\begin{array}{l}\text { 1. Compensatory nitrogen } 8 \mathrm{~kg} \text { t of straw, without } \\
\text { biological preparations (control) }\end{array}$ & $0.204 \mathrm{a}$ & $1.17 \mathrm{c}$ & $0.059 \mathrm{a}$ & $0.337 \mathrm{a}$ & $0.190 \mathrm{a}$ \\
\hline 2. Ruinex 11 ha & $0.201 \mathrm{a}$ & $1.33 \mathrm{ab}$ & $0.050 \mathrm{a}$ & $0.280 b^{*}$ & $0.139 \mathrm{~b}$ \\
\hline 3. Penergetic $\mathrm{k} 0,21$ ha & $0.196 \mathrm{a}$ & $1.41 \mathrm{a}$ & $0.060 \mathrm{a}$ & $0.258 b$ & $0.139 \mathrm{~b}$ \\
\hline 4. Azofix 11 ha & $0.210 \mathrm{a}$ & $1.23 \mathrm{bc}$ & $0.049 \mathrm{a}$ & $0.330 \mathrm{a}$ & $0.195 \mathrm{a}$ \\
\hline 5. Ruinex 11 ha + Penergetic $\mathrm{k} 0,21$ ha & $0.229 \mathrm{a}$ & $1.38 \mathrm{ab}$ & $0.056 \mathrm{a}$ & $0.317 \mathrm{a}$ & $0.181 \mathrm{a}$ \\
\hline 6. Ruinex 11 ha + Azofix 0.51 ha & $0.217 \mathrm{a}$ & $1.39 \mathrm{ab}$ & $0.056 \mathrm{a}$ & $0.279 b$ & $0.149 \mathrm{~b}$ \\
\hline 7. Penergetic $\mathrm{k} 0,21$ ha Azofix 11 ha & $0.210 \mathrm{a}$ & $1.27 \mathrm{~b}$ & $0.058 \mathrm{a}$ & $0.276 \mathrm{~b}$ & $0.146 b$ \\
\hline \multirow[t]{2}{*}{ 8. Ruinex 11 ha+ Penergetic k 0,2 1 ha Azofix 0.5 ha } & $0.205 \mathrm{a}$ & $1.48 \mathrm{a}$ & $0.058 \mathrm{a}$ & $0.261 b^{*}$ & $0.147 \mathrm{~b}$ \\
\hline & \multicolumn{5}{|c|}{ Ploughless tillage (disking) (Factor A) } \\
\hline $\begin{array}{l}\text { 1. Compensatory nitrogen } 8 \mathrm{~kg} \mathrm{t} \text { of straw, without } \\
\text { biological preparations (control) }\end{array}$ & $0.203 \mathrm{a}$ & $1.19 \mathrm{~b}$ & $0.054 \mathrm{a}$ & $0.339 \mathrm{a}$ & $0.187 \mathrm{a}$ \\
\hline 2. Ruinex 11 ha & $0.222 \mathrm{a}$ & $1.32 \mathrm{ab}$ & $0.051 \mathrm{a}$ & $0.307 \mathrm{ab}^{*}$ & $0.181 \mathrm{ab}$ \\
\hline 3. Penergetic $\mathrm{k} 0,21$ ha & $0.212 \mathrm{a}$ & $1.35 \mathrm{a}$ & $0.055 \mathrm{a}$ & $0.276 \mathrm{~b}$ & $0.144 \mathrm{~b}$ \\
\hline 4. Azofix 11 ha & $0.233 \mathrm{a}$ & $1.24 \mathrm{~b}$ & $0.048 \mathrm{a}$ & $0.315 \mathrm{a}$ & $0.168 \mathrm{ab}$ \\
\hline 5. Ruinex 11 ha + Penergetic $\mathrm{k} 0,21$ ha & $0.206 \mathrm{a}$ & $1.35 \mathrm{a}$ & $0.056 \mathrm{a}$ & $0.299 \mathrm{ab}$ & $0.165 \mathrm{ab}$ \\
\hline 6. Ruinex 11 ha + Azofix 0.51 ha & $0.224 \mathrm{a}$ & $1.29 \mathrm{~b}$ & $0.053 \mathrm{a}$ & $0.288 \mathrm{ab}$ & $0.151 \mathrm{ab}$ \\
\hline 7. Penergetic k 0,2 1 ha Azofix 11 ha & $0.210 \mathrm{a}$ & $1.29 \mathrm{~b}$ & $0.048 \mathrm{a}$ & $0.238 \mathrm{~b}$ & $0.148 \mathrm{ab}$ \\
\hline 8. Ruinex 11 ha+ Penergetic $\mathrm{k} 0,21$ ha Azofix 0.5 ha & $0.214 \mathrm{a}$ & $1.47 \mathrm{a}$ & $0.054 \mathrm{a}$ & $0.330 \mathrm{a}^{*}$ & $0.168 \mathrm{ab}$ \\
\hline
\end{tabular}

Note: The differences between the means of the variants (A-no-tillage or ploughless tillage) marked with an asterisk $\left(^{*}\right)$ are significant. The differences between the means of the variants (B-biological preparations) marked with the different letter (a, b, c ...) are significant $(\mathrm{P}<0.05)$.

The soil of our experiment varies between medium and high content of phosphorus (192-412 $\mathrm{mg} \mathrm{kg}^{-1}$ ), therefore a more stable indicator of total phosphorus content is provided. It consists of both mineral and organic compounds. Humus 
is the major component of organic phosphorus, and upon mineralization it becomes available to plants (Shen et al., 2011) . The experiment showed that the total phosphorus content in both tillage technologies varied insignificantly (from $0.048 \%$ To $0.06 \%$ ). There were no significant differences between the biological preparations and their mixtures and the use of compensatory nitrogen in the test fields, but it was observed that the content of total phosphorus tended to decrease compared to the immobile soil when the biological preparations and their mixtures were applied to the soil. Thus, it can be argued that, albeit insignificantly, tillage affected the content of total phosphorus in the soil. Ploughless tillage technology promoted phosphorus mineralization and availability to plants, so there was less of it in this background.

Mobile humic substances and mobile humic acids act as soil improvers and as plant biostimulants. Humic acids, compared to other organic substances, are particularly conducive to the growth of plant biomass and soil fertility. Another very important advantage is that humic acids have a long duration of action because they are not degraded as quickly as other organic fertilizers and improve the soil for up to 2-3 years (Jindo et al., 2012).

With the use of biological products, a reduction in mobile humic substances (MHS) has been observed in most of the variants. In ploughless tillage, a mixture of Azofix and Ruinex + Penergetic $k$ did not significantly reduce MHS in the soil compared to the control. When biological preparations were applied with disc implements (ploughless technology), there were also few cases of more pronounced reductions, and the mixture of all three biological preparations reduced the content of MHS the least. A fundamental difference was found between tillage technologies. When the biological preparation Ruinex was applied and incorporated into the soil, MHS remained $9.6 \%$ higher than when it was simply sprayed on the stubble. After the application of biological preparations in the stubble (no-tillage technology), the content of mobile humic acids (MHA) was not significantly reduced only with the use of Azofix and the mixture Ruinex + Penergetic $k$. Significant decrease in MHA was observed in the ploughless technology, and the use of Penergetic $k$ alone reduced the content of MHA the most (23.0\%). Biological preparations are thought to have promoted the release of MHS and MHA into a form accessible to plants, resulting in lower levels of them in the soil.

\section{CONCLUSIONS}

The use of biological preparations and their mixtures, in many cases, increased the content of water-soluble (labile) carbon in the soil compared to the use of compensatory nitrogen to stimulate straw mineralization. The content of labile carbon was particularly increased by mixtures of two preparations (Ruinex + Penergetic $k$, Ruinex + Azofix and Penergetic $k+$ Azofix) using both tillage technologies. The combination of the three preparations increased the content of soluble carbon by $5.4 \%$ more in ploughless technology, in no-tillage - only $0.5 \%$. The use of one-component biological preparations in ploughless tillage also increased the content of water-soluble carbon, and in no-tillage - reduced it but insignificantly.

The organic carbon content of the soil was not significantly affected by tillage technology, and the use of biological preparations and their mixtures increased the organic carbon content of the soil. The total phosphorus was not significantly affected by the tillage technology or the biological preparations used, only the tendency was observed that the loosening of the soil promotes its relaxation and accessibility to plants.

Significant reductions in MHS and MHA were found in the crop of no-tillage technology compared to the use of nitrogen. These substances were particularly reduced by the use of a mixture of all three preparations without their incorporation into the soil, using a no-tillage technology.

\section{REFERENCES}

1. Arai Y., Sparks D. L. 2007. Phosphate reaction dynamics in soils and soil minerals: a multiscale approach. Advances in Agronomy, Vol. 94, p. 135-179. https://doi.org/10.1016/S0065-2113(06)94003-6

2. Arlauskienė A., Velykis A., Šlepetienè A., Janušauskaitè D. 2014. Stimulation of cereal straw decomposition in the initial stages of decomposition. Recent Recommendations for Agriculture and Forestry, p. 7 - 11.

3. Baumhardt R. L., Stewart B. A., Sainju, U. M. 2015. North American soil degradation: Processes, practices, and mitigating strategies. Sustainability, Vol. 7.3 pp. 2936-2960. https://doi.org/10.3390/su7032936

4. Das R., Purakayastha T. J., Das D., Ahmed N., Kumar R., Biswas S., Datta S. C. 2019. Long-term fertilization and manuring with different organics alter stability of carbon in colloidal organo-mineral fraction in soils of varying clay mineralogy. Science of the Total Environment, Vol. 684, pp. 682-693. https://doi.org/10.1016/j.scitotenv.2019.05.327

5. Jakienė E., Venskutonis V. 2008. Growth regulators in crop production. Akademija, 80 p.

6. Jakienè E. 2011. Efficiency of the use of biological preparations in sugar beet crop. Agricultural Sciences, Vol. 18(2), p. 64-71.

7. Jindo K., Martim S. A., Navarro E. C., Pérez-Alfocea F., Hernandez T., Garcia C., Canellas L. P. 2012. Root growth promotion by humic acids from composted and non-composted urban organic wastes. Plant and Soil, Vol. 353(1), pp. 209-220. https://doi.org/10.1007/s11104-011-1024-3

8. Kaiser K., Kalbitz K. 2012. Cycling downwards - dissolved organic matter in soils. Soil Biology and Biochemistry, Vol. 52, p. 29-32. 
9. Kumar R., Saurabh K., Kumawat N., Mishra J. S., Hans H., Krishna B., Meena R. S., Jha B. K., Upadhyay P, K., Hazra K. K. 2019. Conservation Agriculture: Perspectives on Soil and Environmental Management in IndoGangetic Plains of South Asia. In: Meena R., Kumar S., Bohra J., Jat M. (eds) Sustainable Management of Soil and Environment. Springer, Singapore, pp. 123-168. https://doi.org/10.1007/978-981-13-8832-3_4

10. Lal R. 2011. Sequestering carbon in soils of agroecosystems. Food Policy, Vol. 36, p. $33-39$. https://doi.org/10.1016/j.foodpol.2010.12.001

11. Mikučionienė R., Vaisvalavičius R., Aleinikovienė J., Smalstienė V. 2017. Evaluation of soil organic matter and biological activity in different crop rotations. Human and Nature Safety, p. 152-155.

12. Paradikovic N., Vincovic T., Vrcek, I., Zuntar I., Bojic M., Medic-Saric M. 2011. Effect of natural biostimulants on yield and nutritional quality: an example of sweet yellow pepper (Capsicum annuum L.) plants. Journal of the Science of Food and Agriculture, Vol. 91, pp. 2146 - 2152. https://doi.org/10.1002/jsfa.4431

13. Raudonius S. 2017. Application of statistics in plant and crop research: important issues. Žemdirbyste-Agriculture, Vol. 104, p. 377-382. https://doi.org/10.13080/z-a.2017.104.048

14. Shen J., Yuan L., Zhang J., Li H., Bai Z., Chen X., Zhang F.2011. Phosphorus Dynamics: From Soil to Plant. Plant Physiology, Vol. 156, pp. 997-1005. https://doi.org/10.1104/pp.111.175232

15. Sheridan W. L., Ruocco, M., Vinale, F., Nigro, M., Marra, R., Lombardi, N., Lorito, M. 2014. Trichoderma-based Products and their widespread use in Agriculture. The Open Mycology Journal, Gol. 8, pp. 71-126. https://doi.org/10.2174/1874437001408010071

16. Staugaitis Ž., Šlepetienė A., Tilvikienè V. Kadžiulienè, Ž. 2016. Total and labile carbon in the soil during fertilization of chicory with mineral fertilizers and by-product of biogas production. Agricultural Sciences, vol. 23(3), p. 123-129. https://doi.org/10.6001/zemesukiomokslai.v23i3.3359

17. Tripolskaja L., Šidlauskas G. 2010. Influence of catch crops on green manure and straw on atmospheric precipitation filtration and nitrogen leaching. Žemdirbystè-Agriculture, Vol. 97(1), p. 83 - 92.

18. Zhang M. Z. X., Liang W. J., Jiang Y., Dai G. H., Wang X. G., Han S. J. 2011. Distribution of soil organic carbon fractions along the altitudinal gradient in Changbai Mountain, China. Pedosphere, Vol, 21(5), p. 615-620. https://doi.org/10.1016/S1002-0160(11)60163-X 